\title{
EVALUATION ON RESIDUAL MONOMER OF HDDMA MATRIX SYSTEM ON FIDER REINFORCED CONDOSITES (FRC)
}

\author{
(EVALUASI MONOMER RESIDU DARI SISTEM MATRIKS HDDMA \\ PADA FIDER REINFORCED CONDOSITES(FRC)
}

\author{
Siti Sunarintyas*, Widowati Siswomihardjo*, Dyah Irnawati*, Jukka Pekka Matinlinna** \\ *Faculty of Dentistry, Gadjah Mada University, Indonesia \\ **University of HongKong, HongKong, China \\ Jl. Denta Sekip Utara, Yogyakarta 55281 \\ E-mail: sunarintyassiti@ugm.ac.id
}

\begin{abstract}
Matrix system used bis-GMA was reported hazardously. An alternative monomer such as 1,6-hexanediol dimethacrylate (HDDMA) was under research. The aim of this study was to evaluate residual monomer content of HDDMA based matrix compositions on FRCs (fiber-reinforced composites). Three monomers based on bis-GMA (Sigma-Aldrich,USA), methylmethacrylate (MMA, ProSciTech, Australia), HDDMA (Esstech, USA) were used and also camphorquinone (CQ, Esstech, USA), N,N-cyanoethyl methylaniline (CEMA, Esstech, USA), E-glass fibers (StickTech, Finland). The matrix ratios (weight \%) were 78.4\% bis-GMA+19.6\% MMA+1.0\% CQ+1.0\% CEMA (control-group), 78.4\% HDDMA+ $19.6 \% \mathrm{MMA}+1.0 \% \mathrm{CQ}+1.0 \%$ CEMA (EXP-1group), and 49.0\% HDDMA+49.0\% MMA $+1.0 \% \mathrm{CQ}+1.0 \% \mathrm{CEMA}$ (EXP-2group). Samples with fibers embedded in matrix were light-cured then powdered. Powder of 150mg was diluted in acetonitrile to $10 \mathrm{ml}$. The solution was filtered then injected into HPLC $(20 \mu \mathrm{L})$. Residual monomer content was evaluated by mobile phase of acetonitrile and water of 7:3, flow rate $1 \mathrm{~mL} /$ minute. The size of column was $\mathrm{C} 185 \mu$, $125 \mathrm{~mm}$ length, $4 \mathrm{~mm}$ diameter. UV detection used $275 \mathrm{~nm}$. Data were analyzed by ANOVA. The result showed the average of residual monomer content (in \%) was: $0.02125 \pm 0.00018$ (control-group), $0.01660 \pm 0.00016$ (EXP-1group), $0.01676 \pm 0.00033$ (EXP-2group). The ANOVA showed significant difference of monomer content among the groups $(\mathrm{p}<0.05)$. The LSD showed significant difference between EXP-1 and control-groups; also between EXP-2 and controlgroups $(\mathrm{p}<0.05)$. There was no significant difference between EXP-1 and EXP-2 groups $(\mathrm{p}>0.05)$. In conclusion, a resin matrix system based on HDDMA-MMA (EXP-1 and EXP-2 groups) revealed significant difference of residual monomer content to bis-GMA-MMA (control-group) system. The HDDMA-MMA matrix system had less residual monomer content than bis-GMA-MMA.
\end{abstract}

Key words: residual-monomer, fiber-reinforced composite, 1,6-hexanediol dimethacrylate

\begin{abstract}
Abstrak
Sistem matriks berbasis bis-GMA dilaporkan bersifat kurang aman bagi tubuh. Monomer alternatif 1,6-hexanediol dimethacrylate (HDDMA) sedang dalam penelitian. Tujuan penelitian ini adalah mengevaluasi jumlah kandungan monomer residu sistem matriks HDDMA pada FRC(fiber-reinforced composite). Tiga komposisi monomer digunakan dalam penelitian yaitu bis-GMA (Sigma-Aldrich, USA), methylmethacrylate (MMA, ProSciTech, Australia), HDDMA (Esstech, USA), serta camphoroquinone (CQ, Esstech, USA), N,N-cyanoethyl-methylaniline (CEMA, Esstech, USA), Eglassfibers (Sticktech, Finland). Rasio matriks resin (\% berat): bis-GMA 78,4\% + MMA 19,6\% + CQ 1,0\% + CEMA 1,0\% (kelompok kontrol), HDDMA 78,4\% + MMA 19,6\% + CQ 1,0\% + CEMA 1,0\% (kelompok EXP-1), dan HDDMA 49,0\%+MMA 49,0\% + CQ 1,0\% + CEMA 1,0\% (kelompok EXP-2). Sampel dengan fiber dalam matriks disinari kemudian diserbuk. Serbuk $150 \mathrm{mg}$ dilarutkan dalam acetonitrile hingga 10mL. Larutan disaring, kemudian diinjeksikan ke dalam HPLC $20 \mu \mathrm{L}$. Jumlah monomer residu dievaluasi menggunakan mobile phase acetonitrile dan air dengan rasio 7:3, kecepatan alir $1 \mathrm{~mL} /$ menit. Ukuran kolom adalah C $185 \mu \mathrm{m}$, panjang $125 \mathrm{~mm}$, diameter $4 \mathrm{~mm}$. Deteksi UV menggunakan panjang gelombang $275 \mathrm{~nm}$. Data dianalisis menggunakan ANOVA. Hasil penelitian menunjukkan rerata kandungan monomer residu (\%): 0,02125 \pm 0,00018 (kelompok kontrol), 0,01660 $\pm 0,00016$ (kelompok EXP-1), dan 0,01676 $\pm 0,00033$ (kelompok EXP-2). Hasil Uji ANOVA menunjukkan perbedaan signifikan kandungan monomer antar kelompok $(\mathrm{p}<0,05)$. Uji LSD menunjukkan perbedaan signifikan antara kelompok EXP-1 dan kontrol, juga EXP-2
\end{abstract}


dan kontrol, sedangkan antara EXP-1 dan EXP-2 tidak ada perbedaan signifikan ( $>>0,05)$. Sebagai kesimpulan, sistem matriks resin berbasis HDDMA-MMA (kelompok EXP-1 dan EXP-2) menunjukkan perbedaan signifikan jumlah kandungan monomer residu terhadap sistem bis-GMA-MMA (kelompok kontrol). Sistem matriks HDDMA-MMA menunjukkan kandungan monomer residu lebih kecil dari sistem matriks bis-GMA-MMA.

Kata kunci: monomer residu, fiber-reinforced composite, 1,6-hexanediol dimethacrylate

\section{INTRODUCTION}

One new group of non-metallic dental biomaterials is fiber-reinforced composites (FRCs). Fiberreinforced composites are a novel group of materials that are characterized by reinforcing fibers embedded in a polymer matrix. The reinforcing fibers prevent crack propagation by chemically bonding to the polymer matrix with covalent bonds. ${ }^{1}$ The use of FRCs is growing in many dental applications, such as in fixed partial dentures (FPD), periodontal splints, endodontic posts, orthodontic appliances, and some other indirect restorations. ${ }^{2}$ Previous research reported that some commercial FRCs had flexural moduli and strengths seven times those of composite resins with particulate fillers. ${ }^{3}$

Matrix of FRC consists of polymerized monomers with the function of holding fibers together in the composite structure. It also transfers stresses between fibers and protects the fibers from the outside environment such as chemicals, moisture and mechanical shocks. Matrix may influence the compressive strength, interlaminar shear and inplate shear properties, interaction between the matrix and the fiber and defects in the composite. ${ }^{4}$

There are two kinds of resin matrix which are used in dental FRCs: the crosslinked and linear polymers. The crosslinked polymer which is also called a thermoset polymer is multifunctionnal or dimethacrylate resins. The linear polymer is also called a thermoplastic polymer referring to monofunctional methacrylate polymers. ${ }^{5}$ In FRCs with an IPN (inter penetrating network) structure, the matrix consists of a crosslinking polymer, a linear polymer and a photoinisiator. $^{6}$

The monomer system can be viewed as the backbone of the FRCs matrix system. Bis-GMA (bisphenol-a-glycidyl-dimethacrylate, Figure 1) continues to be the mostused monomer for manufacturing presentday composites. ${ }^{7}$ It constitutes around $20 \%(\mathrm{v} / \mathrm{v})$ of standard composite resin compositions. ${ }^{8}$ Rigid aromatic backbone structures in bis GMA provide superior toughness to composites, while a main disadvantage is its high viscosity attributed to intermolecular hydrogen bonding between hydroxyl groups, necessitating a diluents monomer such as MMA (methyl methacrylate), TEGDMA (triethyleneglycol dimethacrylate), UDMA (urethane dimethacrylate) and HEMA (hidroxy ethyl methacrylate). ${ }^{9}$ The addition of TEGDMA is reported improves handling characteristics and filling loadings, however dilution also increases polymerization shrinkage and water sorption. ${ }^{10}$ To overcome adverse diluents effects on properties of dental composites, several studies aimed at developing bisGMA alternatives with lower viscosities. ${ }^{11-13}$<smiles>C=C(C)C(=O)OCC(O)COc1ccc(C(C)(C)c2ccc(OCC(O)COC(=O)C(=C)C)cc2)cc1</smiles>

Figure 1. The chemical structure of bis-GMA ${ }^{7}$

In the development of new polymeric matrix based for dental use, it is important to know the extent of residual monomer of the polymerized composites because of the possible harmful effects of the residual monomers on tissues. The monomers that had not reacted (i.e.residual monomer) can leach out from the polymer. The leaching of the residual monomers from the composite in the body has been suggested to cause adverse tissue reactions such as allergic reactions, or the monomers can even be estrogenic in nature. ${ }^{14}$

It is reported that bis-GMA becomes the most cytotoxic monomer among 35 dental resin composite monomers includes bis-GMA, GMA, HDDMA, BPA, CQ, TEGDMA, HEMA, MMA, etc. ${ }^{15}$ Other author reported that bis-GMA had strong haemolytic potency due to the chemical structure with a high hydrolytic nature. ${ }^{16}$ The aromatic bis-GMA is slightly more cytotoxic than aliphatic monomer UDMA. ${ }^{17,18}$ Cell toxicity was observed at $b$ is-GMA concentrations of $50 \mathrm{pg} / \mathrm{ml}$ and higher. ${ }^{19}$ In fact, recent commercial matrix system of FRCs used bis-GMA system as the basic matrix component. To reduce the harmfully effect of such matrix system, it is necessary to look for a new saver matrix system for human

instead of bis-GMA.

Resin matrix 1,6 hexanediol dimethacrylate (HDDMA, Figure 2) has similar reactive group to bis-GMA. The HDDMA properties are low 
viscosity, fast curing monomer with low volatility, hydrophobic backbone, and good solvency for use in free radical polymerization. ${ }^{20}$ The HDDMA has water repellency property (hydrophobic). It is used as a functional monomer for polymers and as a cross-linking agent between molecular chains of polymers. The HDDMA has been used for adhesives and sealants, coatings, elastomer, photopolymers electronics, improved adhesion, hardness, abrasion and heat resistance. ${ }^{21}$ It is reported that none of HDDMA components are listed by IARC, NTP, OSHA, ACGIH, as carcinogens. Moreover HDDMA is reported not to produce mutagenic, embryo toxic, teratogenic, or reproductive effects in human. ${ }^{20}$ The objective of this current study was to evaluate residual monomer content of HDDMA matrix system on FRCs comparing to bis-GMA matrix system.

$$
\underset{\mathrm{CH}_{3}}{\stackrel{\mathrm{o}}{\mathrm{Cl}}} \underset{\mathrm{C}}{\mathrm{C}}-\mathrm{O}-\mathrm{CH}_{2}-\mathrm{CH}_{2}-\mathrm{CH}_{2}-\mathrm{CH}_{2}-\mathrm{CH}_{2}-\mathrm{CH}_{2}-\mathrm{O}-\stackrel{\mathrm{O}}{\mathrm{C}}-\underset{\mathrm{C}}{\mathrm{C}}=\mathrm{CH}_{3}
$$

Figure 1 . The chemical structure of HDDMA ${ }^{20}$

\section{MATERIALS AND METHODS}

The materials used in this study were bis-GMA (Sigma-Aldrich, USA), methylmethacrylate (ProSciTech, Australia), HDDMA (Esstech, USA), and camphorquinone (Esstech, USA), N, N-cyanoethyl methylaniline (Esstech, USA), E-glass fibers (StickTech Ltd., Turku, Finland), and chemical reagent for HPLC analysis with PA grade (Sigma-Aldrich, USA). The fibers used were unidirectional fiber. The E-glass fibers (R338-2400/V/P) were already silanized by the manufacturer and kept in desiccators for $24 \mathrm{~h}$ prior to specimen preparation. The fibers were sized by immersion in a sizing solution (50 wt $\%$ bis-GMA $+50 \mathrm{wt} \%$ MMA for the control group; $50 \mathrm{wt} \%$ HDDMA + 50\% MMA for experimental groups) for $1 \mathrm{~min}$. The sized fibers were cut into $25 \mathrm{~mm}$ long reinforcement with a surgical steel knife for the preparation of test specimens. ${ }^{22}$

The specimen preparation was adapted from Zhang and Matinlinna method. ${ }^{22}$ Two bundles of the prepared $25 \mathrm{~mm}$ long reinforcement were placed along the long axis of the specimen into the mould and embedded into the resin matrix. The matrix compositions were:

Control group: $78.4 \%$ bis-GMA + 19.6\% MMA + $1.0 \% \mathrm{CQ}+1.0 \%$ CEMA

Experiment-1 (EXP-1 group): 78.4\% HDDMA + $19.6 \% \mathrm{MMA}+1.0 \% \mathrm{CQ}+1.0 \%$ CEMA

Experiment-2 (EXP-2 group): 49.0\% HDDMA + $49.0 \% \mathrm{MMA}+1.0 \% \mathrm{CQ}+1.0 \%$ CEMA
For each composition, twelve identical rectangular specimens with dimensions $2 \mathrm{~mm} \times 2 \mathrm{~mm}$ × $25 \mathrm{~mm}$ were prepared. Air bubbles were removed carefully by pressing the fiber bundles with a hand instrument. The resin matrix was light cured with a halogen light curing unit on both sides of the specimens for $3 \times 40 \mathrm{~s}$. The average light intensity was $700 \mathrm{~mW}$ $/ \mathrm{cm}^{2}$ measured with Cure Rite ${ }^{\mathrm{TM}}$ Model 8000 hand held radiometer, and the wavelength range of the curing unit was $400-500 \mathrm{~nm}$. The specimen then powdered by diamond dental bur.

The residual monomer testing was adapted from ISO 3696: 1987 (E). ${ }^{23}$ HPLC was used to quantity the residual monomer content of the HDDMA matrix system and bis-GMA matrix system. A sample of $150 \mathrm{mg}$ was diluted in ace-tonitrile to 10 $\mathrm{ml}$. Magnetic stirrer was used to dissolve the solution (72 h). The supernatant of the solution was filtered through a $0.45 \mu \mathrm{m}$ pore Millipore filter. The solution of $20 \mu \mathrm{L}$ was injected into the HPLC. Residual monomer content was evaluated using the mobile phase of ace-tonitrile and water with 7:3 ratio, flow rate $1 \mathrm{~mL} /$ minute. The size of column was $\mathrm{C} 185 \mu$, length $125 \mathrm{~mm}$, and $4 \mathrm{~mm}$ in diameter. UV detection used $275 \mathrm{~nm}$.

The linear fitting of bis-GMA and HDDMA calibration curve used to calculate the concentration of each residual monomer in the sample solution, based on the area of the chromategraphic peaks at the corresponding retention times. Data were analyzed by one way analysis of variance (ANOVA) followed by Post Hoc test of LSD. P-values less than 0.05 were considered to be statistically significant in all tests.

\section{RESULTS}

The concentration of bis-GMA residual monomer from E-glass FRC was obtained by calculating the peak area of the specimen using the formula of $y=$ $0.9998 \times+6.2728 \times 10^{-3}$ from the standard bisGMA curve; while for HDDMA re-sidual monomer from the formula of $y=0.9877 \mathrm{x}+6.0253 \times 10^{-3}$ from the standard HDDMA curve. The average concentration of residual monomer of bis-GMA or HDDMA obtained in weight percentage was shown in Table 1.

Table 1. Residual monomer concentration (\%)

\begin{tabular}{cc}
\hline Matrix & Mean \pm \\
composition & S.D. \\
\hline Control group & $0.02125 \pm 0.00018$ \\
EXP-1 group & $0.01660 \pm 0.00016$ \\
EXP-2 group & $0.01676 \pm 0.00033$ \\
\hline
\end{tabular}


The residual monomer evaluation revealed the control-group (bis-GMA matrix system) mean value was higher than the EXP-1 group and the EXP-2 group (HDDMA matrix system). Statistical analysis by one way ANOVA showed significant difference of residual monomer content among the groups $(\mathrm{p}<0.05)($ Table 2$)$.

Table 2. The ANOVA of residual monomer content

\begin{tabular}{lccc}
\hline Source & f & F & Sig \\
\hline Between group & 2 & & \\
EXP-1 group & 15 & 1797.87100 & 0.00001 \\
EXP-2 group & 17 & & \\
\hline
\end{tabular}

Further Post Hoc analysis by LSD showed significant difference between EXP-1 and controlgroups; and also between EXP-2 and control-groups $(\mathrm{p}<0.05)$; whilst no significant difference between EXP-1 and EXP-2 groups ( $>>0.05)$ (Table 3).

Table 3. The Post Hoc LSD of residual monomer content

\begin{tabular}{cccc}
\hline Group & $(\mathrm{J})$ Group & $\begin{array}{c}\text { Mean Difference } \\
(\mathrm{I}-\mathrm{J})\end{array}$ & Sig \\
\hline EXP-1 & EXP-2 & 0.00017 & 0.07800 \\
& Control & $0.00465^{*}$ & 0.00001 \\
EXP-2 & EXP-1 & 0.00017 & 0.07800 \\
& Control & $0.00448^{*}$ & 0.00001 \\
Control & EXP-1 & $0.00465^{*}$ & 0.00001 \\
& EXP-2 & $0.00448^{*}$ & 0.00001 \\
\hline
\end{tabular}

\section{DISCUSSION}

As a less invasive dental tissue saving treatment, fiber reinforced composite resins (FRCs) have gained more and more interest in dentistry. There are two main parts in FRCs, the matrix component and the fiber. Two major types of polymer matrices used in FRCs, namely cross-linked and linear polymers. The cross-linking polymer refers to multifunctional dimethacrylate resins. The linear polymer refers to a monofunctional methacrylate polymer. In FRCs with the socalled IPN structure, usually the matrix consists of a cross-linking polymer and a linear polymer.

The basic component of commercially FRCs matrix is bis-GMA. Many researches proved the negative side effect of bis-GMA. ${ }^{17-19}$ Bis-GMA is known as a highly viscous monomer, makes difficult to be handled. The current research had the objectives of replacement the matrix of bis-GMA based to HDDMA based in FRCs and evaluate their residual monomer content.

Table 1 showed that resin matrix system based on HDDMA revealed less residual monomer content than bis-GMA on FRC. It might be in-fluenced by the chemical structure characteristic of hydrophobic backbone of HDDMA and also its volatility properties. Figure 2 showed that HDDMA did not have hydroxyl groups and aromatic structures as bisGMA. Previous research reported that removal hydroxyl groups in bis-GMA and increased the steric hindrance in the chain packing of the polymer was effective for viscosity reduction. The lower viscosity and weaker hydroxyl bonding of monomer mixtures increase the mobility of the monomer system, thereby allowing the material to reach a much higher double-bond conversion. ${ }^{24}$

It was reported that the matrix system with increased mobility of monomer molecules and weaker molecular interactions possessed the highest conversion compared to bis-GMA matrix system with stronger hydrogen bonding. Besides, flexibility of monomer molecules was inhibited with increasing the size and steric hindrance of substituent especially for benzoyl group, resulting in the lowest conversion. These results suggested that viscosities of monomer mixtures and molecular structure of monomers are essential for vinyl conversion and therefore affect the properties of the matrix system. ${ }^{25}$

The EXP-1 group and EXP-2 group statistically showed no significant difference in residual monomer content might be caused by the same structural characteristic of the material properties. Table 1 revealed that residual monomer content of EXP-1 group was higher than EXP-2 group. This result might cause by the higher percentage of HDDMA of EXP-1 group. By the fact that the EXP-1 group had lower mean percentage of residual monomer content than the EXP-2 group, it is recommended that the EXP-1 group to be evaluated further for the replacement alternative of bis-GMA matrix system on FRC.

This study suggested that a resin matrix system based on HDDMA-MMA (i.e. the Exp-1 and Exp-2 groups) revealed a significant difference of residual monomer content to bis-GMA-MMA (control-group) system. The HDDMA-MMA matrix system showed less residual monomer content than bis-GMA-MMA matrix system.

\section{ACKNOWLWDGEMENT}

This work is financially supported by DP2M Kementrian Ristek dan Pendidikan Tinggi Indonesia for KLN scheme 2014-2015.

\section{References}

1. Valittu PK. Glass fibers in fiber-reinforced com- 
posites. In Matinlinna JP ed. Handbook of oral biomaterials. $1^{\text {st }}$ ed., Singapore: Pan Stanford Publishing Pte Ltd, 2014: 255-79.

2. van Noort R. Introduction to dental materials. $3^{\text {rd }}$ ed., Edinburgh: Mosby Elsevier,2007:120-1.

3. Goldberg M. In vitro and in vivo studies on the toxicity of dental resin components. A review. Clin Oral Investig 2008; 12: 1-8.

4. Lung CYK, Matinlinna JP. Aspects of silane coupling agents and surface conditioning in dentistry: an overview. Dent Mater 2012; 5: 46777.

5. Mallick PK. Fiber-reinforced composites: materials, manufacturing, and design. $3^{\text {rd }}$ ed. Florida: CRC Press Boca Raton, 2008: 1-20.

6. Valittu PK. Interpenetrating polymer networks (IPNs) in dental polymers and composites. In Matinlinna JP, Mittal KL eds. Adhesion aspects in dentistry. $1^{\text {st }}$ ed., Leiden: Koninklijke Brill NV, 2009: 63-74.

7. Gajewski VES, Pfeifer CS, Froes-Salgado NRG, Boaro LCC, Braga RR. Monomers used in resin composites: degree of conversion, mechanical properties and water sorption/solubility. Braz Dent J 2012; 23: 50-5.

8. Zhang M, Matinlinna JP. E-glass fiber reinfor-ced composites in dental application. Silicon 2012; 4:738.

9. Suh BI. Principles of adhesion dentistry: a theoretical and clinical guide for dentists. $1^{\text {st }}$ ed., Newtown: AEGIS Publications LLC, 2013: 5997.

10. Podgorski M, Synthesis and characterization of acetyloxypropylene dimethacrylate as a new dental monomer. Dent Mater 2011; 27: 748-54.

11. Jeon MY, Yoo SH, Kim JH, Kim CK, Cho BH. Dental restorative composite fabricated from a novel organic matrix without an additional diluents. Biomacromolecules 2007; 8: 2571-5.

12. Podgorski M. Synthesis and characterization of novel dimethacrylates of different chain lengths as possible dental resins. Dent Mater 2010; 26:188-94.

13. Podgorski M. Structure-property relationship in new photo-cured dimethacrylate-based dental resins. Dent Mater 2012; 28:398-409.
14. Mallineni SK, Nuvvula S, Matinlinna JP, Yiu CKY, King NM. Biocompatibiliy of various dental materials of contemporary dentistry: a narrative insight. J Investigat Clin Dent, 2013; 4: 9-19.

15. Moharamzadeh $\mathrm{K}$, Brook IM, Van Noort $\mathrm{R}$. Biocompatibility of resin-based dental mate-rials. Material 2009; 2: 514-48.

16. Hedge MN, Wali A. Bis-GMA and TEGDMA elution from two flowable nanohybrid resin composites: an in vitro study. Brit J Med and Med Res 2015; 5: 1096-104.

17. Becher R, Kopperud HM, Al RH, Samuelsen J, Moribak E, Dahlman HJ, et al. Pattern of cell death after in vitro exposure to GDMA, TEGDMA, HEMA and two compomer extracts. Dent Mater 2006; 22: 630-40.

18. Moharamzadeh K, van Noort R, Brook IM, Scutt AM. Cytotoxicity of resin monomers on human gingival fibroblasts and $\mathrm{HaCa}$ keratino-cytes. Dent Mater 2007; 23: 40-4.

19. Rathee M, Malik P, Singh J. Bisphenol A in dental sealants and its estrogen like effect. Indian J Endrocrinol Metab 2012; 16: 339-342.

20. Zhang JF, Wu R, Fan Y, Liao S, Wang Y, Wen ZT, et al. Antibacterial dental composites with chlorhexidine and mesoporous silica. J Dent Res 2014; 12: 1283-9.

21. Stansbury JW. Dimethacrylate network forma-tion and polymer property evolution as deter-mined by the selection of monomers and curing conditions. Dent Mater 2012; 28: 13-22.

22. Zhang M, Matinlinna JP. E-glass fiber-re-inforced composites in dental use. Silicon 2012; 4: 73-78.

23. ISO 3696. Biologic evaluation of medical devices, 2009: 24-8.

24. Martinez-Lozano MA, Cabanes-Vila J, BarjauEscribano A, Fos-Galve P. Composite resins, a review of the materials and clinical indications. Med Oral Patol Oral Cir Bucal 2006; 11: 215-20.

25. Wang R, Zhu M, Bao S, Liu F, Jiang X, Zhu M. Synthesis of two bis-GMA derivates with different size substituent as potential monomer to reduce the polymerization shrinkage of dental restorative composites. J Mater Res 2013; 4: 12-22. 